\title{
Monopolizing Our Bodies? The Myriad Supreme Court Case and Issues of Access and Justice
}

\author{
Nanette Elster • Kayhan Parsi
}

Published online: 13 October 2013

(C) Springer Science+Business Media New York 2013

\begin{abstract}
The actress Angelina Jolie's disclosure that she had a double mastectomy in 2013 shed a great deal of attention on the BRCA1 and BRCA2 genes. This disclosure was made concurrently with the June 13, 2013 U.S. Supreme Court decision in the case of Association for Molecular Pathology v. Myriad Genetics. The court held unanimously that naturally occurring DNA segment was a product of nature and thus not patent eligible but that complementary DNA (cDNA) was patent eligible. Now with the dismantling of Myriad's patent monopoly on the genetic test, issues of access remain but the response of Myriad to develop a financial assistance program illustrates how influential the case may be in changing behavior. Improving accessibility to such tests while still incentivizing the creators of new technologies is a difficult balance to strike. It is one, however, that must be achieved.
\end{abstract}

Keywords Genetics · Genetic testing - Myriad genetics · BRCA1 - BRCA2 - Patents · Access · Justice $\cdot$ Breast cancer · Disparities

Women are diagnosed with breast cancer every day. According to the National Cancer Institute, more than 232, 000 new cases of breast cancer in women were reported in 2013 alone [1]. As heartbreaking as this diagnosis is, very few women share their struggles in an open and public way. This past summer, however, Angelina Jolie did just that. She made headlines for her decision to undergo a double mastectomy

\footnotetext{
N. Elster $(\bowtie) \cdot$ K. Parsi

Neiswanger Institute for Bioethics, Loyola University Chicago

Health Sciences Division, 2160 S. First Avenue,

Bldg 120 Room 280, Maywood, IL 60153, USA

e-mail: nanetteelster@sbcglobal.net

K. Parsi

e-mail: kparsi@lumc.edu
}

after learning that she was positive for the BRCA mutation. Women like Jolie often decide to undergo testing if they have a family history of breast and ovarian cancer in the hopes of preventing their own breast cancer diagnosis. The fact is that only approximately $5-10 \%$ of all breast cancers are the result of the BRCA1 and BRCA2 mutations [2]. Women with either a BRCA 1 or BRCA 2 mutation, however, are at approximately a $50 \%$ increased risk of having breast cancer and a $40 \%$ risk of having ovarian cancer [2]. Although learning that one is a carrier of either of these mutations can be devastating, it also may be empowering - even life-saving - because those who learn that they have the mutation may be able to take prophylactic measures to reduce greatly their risk of developing breast or ovarian cancer. Jolie made this choice. By taking her struggle public, she has become the face of BRCA for the general public, but her story does not really illustrate the enormous controversy that has swirled about the testing for this predictive genetic mutation.

The testing is controversial because of the high cost of the test itself, resulting, in large part, from the patent on the genes held by Myriad Genetics. The patents held by Myriad essentially give the company a legal monopoly on the testing; thus, there has not been any competition to reduce the price of the test, which costs upwards of $\$ 3,000$. The cost of this test was dramatically highlighted in the 2008 documentary In the Family, where filmmaker Joanna Rudnick pointedly asked the CEO of Myriad, Mark Skolnick, why the test is still so expensive at $\$ 3,000$. He sheepishly shrugged his shoulders, suggesting that he really did not have a good answer. This high cost of the test has resulted in handsome profits for Myriad. In 2008, the cost to provide the test was $\$ 32$ million with resultant revenue for Myriad in the range of $\$ 222$ million [3].

Jolie is a woman of means and thus paying $\$ 3,000$ to have a test may not be a great financial burden for her. For many women, however, $\$ 3,000$ for a test that may not be covered by 
insurance and is definitely not covered by Medicaid is simply out of reach. This is especially true if the results of the test are positive. In any event, Jolie placing the issue of screening for breast cancer genes squarely in the eye of the public is commendable; her story has raised awareness not only about the test but about accessibility of the test. Jolie's revelation was made almost simultaneously with the recent $\mathrm{Su}$ preme Court decision of the Myriad Genetics case, highlighting for the general public that this case was as much a question of justice and access to healthcare as it was a question of patent rights.

The Supreme Court of the United States handed down a unanimous decision on June 13, 2013 in the case of Association for Molecular Pathology v. Myriad Genetics. The Court held that a naturally occurring DNA segment was a product of nature and thus not patent eligible but that complementary DNA (cDNA) was patent eligible. The Court distinguished separating human genetic material from actually creating something new, novel, and useful: "In this case...Myriad did not create anything. To be sure, it found an important and useful gene, but separating that gene from its surrounding genetic material is not an act of invention." (Myriad case 2013).

The decision was generally hailed as a coup for patients, physicians, and researchers. A breathless headline in The Scientist a week after the decision triumphantly proclaimed: "Gene Patents Decision: Everybody Wins" [4]. But questions remain. Is the recent Supreme Court decision in Myriad Genetics merely symbolic? With Myriad's patents on the breast cancer genes BRCA1 and BRCA2 set to expire in about 2 years, does the Supreme Court's invalidation of Myriad's patents do much more than send a message about the future of gene patents? The social justice/humanistic concerns raised by Myriad's "monopoly" on testing for BRCA1 and BRCA2 will no longer exist in 2015 with or without the recent Supreme Court decision. This case, however, seems to be about much more than the particular genes at issue. Rather, the case is about the potential dignitary harms that may arise when a "bounty" is placed upon parts of the human body that exist regardless of the intervention of scientists. Did these genes ever really belong to Myriad? This case is an acknowledgment that people are more than the sum of their parts and that although scientific discovery is an essential component of medical progress, it cannot come at the expense of those in need of treatment or care. As James Watson has stated, "DNA's importance flows from its ability to encode and transmit the instructions for creating humans. Life's instructions ought not be controlled by legal monopolies created at the whim of Congress or the courts." [5].

Expensive technologies typically pose challenges for issues of access. Although the Myriad Genetics' test is covered by some insurance plans, not all plans cover this test. For instance, Medicaid does not cover it at all because Myriad does not have preferred provider status. Following the Supreme Court decision, Myriad did implement a financial assistance program for insured and underinsured patients, "[d]ue to regulatory limitations, patients who are recipients of government-funded programs (i.e., Medicaid, Medicare) are not eligible to apply for MFAP" [6]. Now with the dismantling of Myriad's patent monopoly on the genetic test, issues of access remain, but the response of Myriad in developing a financial assistance program illustrates how influential the case may be in changing behavior. If not for the role of patients and human subjects in research, researchers would have no claim for patents at all and thus that which is discovered should be widely available.

The question of access is not new. In 2010, the Secretary's Advisory Committee on Genetics, Health, and Society acknowledged:

Access to genetic tests for significant segments of the population - especially indigent patients - has been impeded when a patent rights holder does not accept all insurers or insurance programs and uses its patent rights to prevent other laboratories from offering the test. Patients covered by the unaccepted insurers or insurance programs cannot afford testing and choose to forgo it [7].

Recently, two companies who announced plans to offer BRCA testing at a fraction of the cost charged by Myriad are being sued by Myriad for patent infringement. This most recent lawsuit again focuses on the financial interests of business entities and researchers while ignoring the life and death decisions of individuals for whom such tests have been developed.

Innovation can and should be rewarded but not at the expense of individuals whose genetic material has not only spurred such innovation but also enabled the research to occur because of their genetic samples. Improving accessibility to such tests while still incentivizing the creators of new technologies is a difficult balance to strike. It is one, however, that must be achieved. By striking such a balance we can ensure that individuals are not only used as a means to an end but also to achieve the public health goals set by Healthy People 2020. These goals include reducing the number of new cancer cases and "[a]chiev[ing] health equity, eliminat[ing] disparities, and improv[ing] the health of all groups." The recent Myriad case reminds us all that there are limits to what we can commodify. Rewarding scientists and researchers for the fruits of their labor should not come at the expense of others trying to access those very innovations.

\section{Compliance with Ethics Guidelines}

Conflict of Interest Nanette Elster and Kayhan Parsi declare that they have no conflict of interest. 
Human and Animal Rights and Informed Consent This article does not contain any studies with human or animal subjects performed by any of the authors.

\section{References}

1. National Cancer Institute. Breast cancer. http://www.cancer.gov/ cancertopics/types/breast/. Accessed 30 Sept 2013.

2. National Cancer Institute. BRCA1 and BRCA2: Cancer risk and genetic testing. http://www.cancer.gov/cancertopics/factsheet/Risk/ BRCA. Accessed 30 Sept 2013.

3. Association for Molecular Pathology v. United States Patent and Trademark Office, 702 F. Supp.2d 181 (2010), citing to Myriad
Genetics, Inc., Annual Report (Form 10-K), at 27 (Aug. 28, 2008).

4. Perkel JM. Gene patents decision: everybody wins. The Scientist 2013. http://www.the-scientist.com/?articles.view/articleNo/36076/ title/Gene-Patents-Decision-Everybody-Wins/.

5. Watson J. Amicus brief filed in: The Association for Molecular Pathology v. Myriad Genetics 2013. http://www.americanbar.org/ content/dam/aba/publications/supreme_court_preview/briefs-v2/12398 neither_amcu_watson.authcheckdam.pdf.

6. Myriad Pro. Myriad Financial Assistance Program. https://www. myriadpro.com/financial-assistance-programs/ Accessed 30 Sept 2013.

7. Secretary's Advisory Committee on Genetics, Health, and Society. Revised draft report on gene patents and licensing practices and their impact on patient access to genetic tests 2010. http://oba.od.nih.gov/ oba/SACGHS/SACGHS\%20Patents\%20Report $\% 20$ Approved $\% 202$ 5-20010.pdf. 